\title{
Brazilian public mental health policy: education and research
}

\author{
Marcos Pacheco de Toledo Ferraz ${ }^{1}$ and Elisaldo A. Carlini²
}

1Professor Titular do Departamento de Psiquiatria da Universidade Federal de São Paulo - UNIFESP

${ }^{2}$ Professor Titular do Departamento de Psicobiologia da Universidade Federal de São Paulo - UNIFESP

Brazil is a country with 170000000 inhabitants (census for the year 2000), of whom 138000000 live in urban areas. The illiteracy rate, that is, people over 15 years of age who cannot write or read even a simple message, is $13.4 \%$. About $25.6 \%$ of the population live on a family income less than half the minimum wage (1999 figures). Brazil's gross internal revenue is $R \$ 564800$ per capita (1998 figures, about U $\$ 1680$ today).

The Brazilian population experiences the diseases typically found in underdeveloped countries as well as the pathologies of developed countries. W th the exception of obstetrics, most of the morbidities found in hospitals are diseases of the respiratory tract $(16.2 \%)$ and those of the circulatory system $(9.5 \%)$, followed by infectious and parasitical diseases (7.4\%). Mental and behavioural disorders account for $3.5 \%$ of hospital cases (see Table 1).

\section{Psychiatric services and reform}

Even though the proportion of psychiatric admissions to hospitals is 3.3\% (Table 1), when we analyse the average expenditure on hospital admissions by the U nified $\mathrm{H}$ ealth System (SU S) by speciality, that is, the amount of expenditure divided by the total number of admissions, the amount spent on psychiatry is about four times higher than that on general practice, and twice as high as that on surgery. The costs of treatment for mental and behavioural disorders, such as schizophrenia, delirious and schizotypal disorders, are far higher than the costs for other disorders (Table 2).

The high costs of schizo phrenia are well demonstrated by Leitão (2001), who, by studying patients with the illness in the state of São Paulo, showed that $2.3 \%$ permanently resided in hospital and $3.7 \%$ had been in hospital for less than one year.

The Conference for the Restructuring of Psychiatric Attention, held by the Pan-American H ealth $O$ rganization in N ovember 1990, passed the Declaration of C aracas, which emphasised a policy of hospital bed reductions and highlighted the frequent violations of human rights that took place at psychiatric hospitals in Latin America. This position had already been adopted by the Brazilian Association of Psychiatry (see below).

There are some 10000 psychiatrists working in Brazil. According to Zago et al (2001), the number of specialists is sufficient (5.75/100 000 inhabitants), but they are largely concentrated in the south and south-east of the country.

Until the mid-1980s, public mental health policies strongly favoured admissions to psychiatric hospitals. This
Table 1. Proportion of hospital admissions by speciality, 2000

\begin{tabular}{lc}
\hline Speciality & Proportion of hospital admissions \\
\hline General practice & $34.3 \%$ \\
Surgery & $23.0 \%$ \\
Obstetrics & $24.1 \%$ \\
Paediatrics & $3.3 \%$ \\
Psychiatry & $3.3 \%$ \\
Psychiatry (day hospital) & $0.2 \%$
\end{tabular}

Source: Ministry of Health - System of Information on Hospitals of the SUS (SIH-SUS).

Table 2. Costs of treatment for mental and behavioural disorders in 2001

\begin{tabular}{|c|c|c|}
\hline Diagnosis & ICD-10 code & $\$ R$ \\
\hline Dementia & F00-F03 & $16,879,254$ \\
\hline $\begin{array}{l}\text { Mental and behavioural disorders due to } \\
\text { the use of alcohol }\end{array}$ & F10 & $60,145,522$ \\
\hline $\begin{array}{l}\text { Mental and behavioural disorders due to the use } \\
\text { of psychoactive substances }\end{array}$ & F11-F19 & $9,061,261$ \\
\hline Schizophrenia, delirious and schizotypal disorders & F20-F29 & $264,195,266$ \\
\hline Mood (affective) disorders & F30-F39 & $31,783,555$ \\
\hline Neurotic and somatoform stress-related disorders & F40-F48 & $1,878,384$ \\
\hline Mental retardation & F70-F79 & $47,668,801$ \\
\hline Other mental disorders & & $56,932,658$ \\
\hline Total & & $488,544,702$ \\
\hline
\end{tabular}

Source: M inistry of Health - System of Information on Hospitals of the SUS (SIH-SUS).

approach has since begun to change, slowly but systematically. As a result, there has been a reduction in both the number of hospital beds in psychiatry and the number of admissions. There were 410003 admissions to psychiatric hospitals in 1997. Data from the Ministry of $\mathrm{H}$ ealth show that this had decreased by $12.8 \%$ in 2001 , in spite of the population growth during the same period. Admissions to day hospitals doubled, from 10268 to 22183.

In April 2001, the Brazilian President passed the Law of Psychiatric Reform after 11 years of discussions in the Congress and wider debates. Law N 0. 10.216 of 6 April 2001 is explicit with regard to the rights of people with mental disorders, in the area of both psychiatric admission and mental health community services. It clearly defines the issue of self-commitment, that is, admission with the consent of the user, as well as invo luntary commitment, which takes place without consent. After extensive discussions, this law determined that the term 'user' should replace the term 'patient'. Involuntary psychiatric admission, 
which must be reported to the Public Ministry by the direction of the hospital, was subject to much controversy but was eventually adopted.

\section{Education in psychiatry}

Websites

tabnet.datasus.gov.br/ cgi/tabcgi.exe?sih/ cnv/miuf.def

portal.saude.gov.br/ saude/aplicacoes/ anuario2001/

recfin/

Mrecfint11.2a.cfm

www.saude.gov.br/ sas/relatorio/

6.7\%20Intervencao. htm
Brazil has at present 95 medical colleges from which about 9300 doctors graduate each year. According to Zago et al (2001), only 16 of them conduct scientific research.

Scientific research in Brazil began in a modern form after the creation of postgraduate education in 1969. In the area of mental health, there has been a very important increase in the number of indexed Brazilian journals since 1990, while the situation in other areas, such as haematology, rheumatology and oncology, has remained the same. Postgraduate programmes have undergone considerable improvement recently. N owadays two centres, the U niversity of São Paulo and the Federal U niversity of São Paulo, gain the best ratings in the external evaluation carried out by the Ministry of Education. 0 ther centressuch as the Federal U niversity of Rio G rande do Sul, the Federal U niversity of Rio de Janeiro and the Federal U niversity of São Paulo (Ribeirão Preto campus) - also showed good results in this evaluation.

\section{Residence in psychiatry}

The $N$ ational C ouncil of Medical Residence (CN RM) was created in September 1977 by means of D ecree 80.281. It defines medical residence as a modality of postgraduate education in the form of specialist courses characterised by in-service training aimed at doctors. The programmes comprise two years in psychiatry, with an optional third year. Presently there are 462 residence places in psychiatry in Brazil, most (43.7\%) of them in the state of São Paulo.

\section{Professional bodies}

The Brazilian Association of Psychiatry (ABP), founded in 1966, has about 3000 associated psychiatrists. It holds congresses (originally biennial and now annual). The last, the XX Brazilian Congress, was attended by 3100 medical professionals, most of whom were psychiatrists.

In June 1993 the ABP was one of the organisers of the 9th World Congress of Psychiatry, held in Rio de Janeiro, which had approximately 7000 participants. The ABP has published the Revista Brasileira de Psiquiatria (Brazilian Psychiatry Journal) since 1979; at first it was called Revista ABP-APAL, when it was jointly produced by the ABP and the Latin-American Psychiatry Association (APAL). The ABP's newsletter, Psiquiatria H oje (Psychiatry Today), was founded in 1976. Both the journal and the newsletter are distributed to all members.

The Association maintains ongoing educational programmes via the internet at www.pecabp.ecurso. com.br

The Institute of Psychiatry at the Federal U niversity of Rio de Janeiro also publishes a journal of good scientific quality and national circulation, the Jornal Brasileiro de Psiquiatria (Brazilian Journal of Psychiatry).

\section{References}

Leitão, R. J. C. (2001) Utilização de Recursos e Custos Diretos da Esquizofrenia para o Setor Público do Estado de São Paulo. Tese de Mestrado em Epidemiologia da Universidade Federal de São Paulo.

Zago, A. M., et al (2001) Ciência no Brasil. Texto preparado para a Academia Brasileira de Ciências.

\title{
Psychiatry in India
}

\section{Vikram Patel ${ }^{1}$ and Shekhar Saxena ${ }^{2}$}

\author{
${ }^{1}$ Senior Lecturer, London School of Hygiene and Tropical Medicine, and the Sangath Society, Goa, India \\ ${ }^{2}$ Coordinator, Mental Health: Evidence and Research, Department of Mental Health and Substance Abuse, WHO, \\ Geneva, Switzerland
}

ndia is a low-income country that is characterised
by huge diversity within and between its 35 states
and union territories. For example, the infant
mortality rate (per 1000 live births) ranges from a
low of 16.3 in Kerala to a high of 86.7 in Uttar
Pradesh, over a fivefold difference (International
Institute for Population Sciences \& ORC Macro,
2001 ). This considerable variation is evident in
virtually every aspect of human development in

India, and any summary figures are likely to be unrepresentative of most parts of the country. W ithin the scope of this short article, this important limitation of averages must be recognised at the outset.

The latest population figures for India show that the population has now crossed the 1 billion mark and is continuing to grow, although at a gradually slower pace than before. The substantial epidemiological evidence base in 